\title{
ラウンドアバウト幾何構造の 安全性能評価のためのリスク指標モデリング
}

\author{
吉岡 慶祐 1 ・中村 英樹 2 ・下川 澄雄 3 ・森田 綽之4 \\ 1正会員 日本大学助手 理工学部交通システム工学科（テ274-8501 千葉県船橋市習志野台7-24-1） \\ E-mail: yoshioka.keisuke@nihon-u.ac.jp \\ 2フェロー会員 名古屋大学大学院教授 環境学研究科（干464-8603 名古屋市千種区不老町 C1-2(651)） \\ E-mail: nakamura@genv.nagoya-u.ac.jp \\ 3正会員 日本大学教授＼cjkstart理工学部交通システム工学科（テ274-8501 千葉県船橋市習志野台7-24-1） \\ E-mail: shimokawa.sumio@nihon-u.ac.jp \\ 4フェロー会員 日本大学客員教授＼cjkstart理工学部交通システム工学科（同上） \\ E-mail: hi-morita@i-transportlab.jp
}

\begin{abstract}
ラウンドアバウトの幾何構造設計では, 単に幾何構造要素の寸法を決定する仕様設計ではなく, 安全性 能照査型の手法が求められる。しかし，わが国では安全性能照査型の設計を行うための評価方法や評価指 標はこれまで検討されていない。 そこで本研究は，ラウンドアバウト幾何構造の安全性能評価指標として， 事故の起きやすさを表す見落とし確率と, 事故が起きた時の重度を示す衝突強度の積で表されるリスク指 標を提案し，その算出方法を提示した. また，任意の幾何構造を対象とした数值シミュレーション結果に 基づき, 幾何構造条件からリスク指標を算出するためのモデル化を行った。 その結果，とくに流入部接続 角度が小さいと見落とし確率が高くなり，また偏差角が小さいほど衝突強度が高くなることが明らかにな った。
\end{abstract}

Key Words : roundabout, geometry, design, safety performance, evaluation index, risk

\section{1. はじめに}

ラウンドアバウトは信号制御を行わないことから，安 全性能は幾何構造設計の如何に委ねられるといっても過 言ではない. ラウンドアバウトの幾何構造設計は，外径， 環道幅員, 流入隅角部などの様々な幾何構造要素によっ て構成され，それらの組合せを決定していくプロセスで ある1).そのプロセスにおいては，単に幾何構造の寸法 を決定していくような仕様設計ではなく, 幾何構造全体 に対して要求される安全性能が満たされるかどうかを評 価し，もし満たされない場合には幾何構造設計を見直す といった安全性能照査型の設計手法が求められる．海外 のいくつかの国では，幾何構造設計に関するガイドライ ン類の中で，安全性能の観点から幾何構造を評価する方 法を提示しており，安全性能照査型の設計方法の枠組み が確立されている。しかしわが国では，幾何構造を評価 するための具体的な評価方法や評価指標はこれまで検討 されていない.

また，国内で環状交差点として運用されているラウン
ドアバウトには，従来からロータリーとして存在してい たものに区画線や歩車道境界ブロックの設置等の簡易な 改良を施しただけのものも多く，特にこれらの中には環 道幅員が広い，エプロン段差が設置されていないといっ た幾何構造の問題により直進車両の走行軌跡が直線的と なり，ラウンドアバウト本来の速度抑制効果が十分に発 揮されていない箇所も散見される．新設のみならず，上 記のような既存ラウンドアバウトの改良を検討するため にも, 安全性能を評価する手法の確立は重要な課題であ ると考えられる.

以上を踏まえ, 本研究ではラウンドアバウトの幾何構 造設計における安全性能照査のための評価方法の確立に 向けての検討の一つとして，事故の起きやすさと事故が 起きた時の重度を考慮した評価指標であるリスク指標を 提案する. また, 幾何構造条件からリスク指標を推定す るモデルを構築することを目的とする. 


\section{2. 幾何構造の安全性能評価に関する知見の整理}

\section{(1) ラウンドアバウトマニュアル}

わが国のラウンドアバウト幾何構造設計に関する技術 指針であるラウンドアバウトマニュアル1)では，幾何構 造設計の基本的な考え方や各幾何構造要素の標準的な諸 元等を示している。これらは，海外の設計指針を参考に しつつ，国内における調査・研究を踏まえて作成された ものである. しかし，安全性能評価に関しては，その必 要性について言及しているものの，手法が未確立である ために定量的な評価方法は示されていない.

一方近年は，既にラウンドアバウトが導入された箇所 において多くの調査・研究が実施されており，幾何構造 設計に関する知見も少しずつ蓄積されている．例えば, (公財)国際交通安全学会の研究プロジェクト2)では, 燒津 市山の手ラウンドアバウト社会実験中における環道幅員 の変更前後の比較から，環道幅員が広い場合において， 直線的な走行軌跡を描くため速度が高くなることを示し ている．飯田市吾妻町の調査では，歩車道境界ブロック 等の設置による簡易的な幾何構造の改良により環道内で の速度や走行位置が変化したことを示している．また小 林ら゙は，試験場に設置されたエプロン段差の走行実験 により，被験者の評価や挙動特性に基づいた適当なエプ ロン高さを示している. このように，個々の幾何構造要 素に対する知見は蓄積されつつあるが，その一方で，本 研究が目的とする幾何構造全体の評価を考えるうえでは, 未だ十分に研究が進んでいるとは言えない状況にある.

\section{（2）海外の安全性能評価方法と適用にあたっての課題}

欧米を中心とした海外諸国では，わが国と比較してラ ウンドアバウトの導入経験も長く安全性能に関する既往 研究も多く見られる。良く知られた研究として, Maycook and Hall') ウトの事故率と幾何構造の関係を調査し，幾何構造条件 から事故率を予測するモデルを構築している．その後同 様に，オーストラリアではAndt and Troutbeck ${ }^{5)}$ ，アメリカ ではTransportation Research Boardのの調査により幾何構造と 事故率の関係をモデル化している．これらは実データに 基づく経験的なモデル式であり，幾何構造に対する安全 性能を評価するための有力な方法であると考えられる. ただし，各国における事故率と幾何構造の関係の傾向は 必ずしも一致しておらず，これは各国のラウンドアバウ トの導入経験や幾何構造特性の違いによるものと考えら れる.したがって，これらのモデル式をそのままわが国 に適用することは不適切である.

また，設計に関するガイドライン類の中で，幾何構造 設計の判断根拠として安全性能を評価する手法を確立し ている国もある．例えばアメリカ7では概略設計の段階 で図面上から想定される走行軌跡(fastest path)を描画し, その軌跡の曲線半径から速度を推定することで幾何構造 の安全性能を評価している．アメリカの評価方法の基本 的な思想は，「速度」を安全性能を規定する一つの代理 指標として捉え，速度と幾何構造の関係を明らかにする ことで幾何構造の安全性能を評価しようとするものであ る. 一方スイス ${ }^{8)}$ では，外径や幅員などの様々な幾何構 造条件によって決定される幾何構造の代表要素である偏 差角(図-6参照 : 海外ではdeviation angleと呼ばれる)を定義 し，偏差角が40deg以上となることを幾何構造設計にお ける要求事項として挙げている. Spacek ${ }^{9}$ の研究では, 偏差角が小さいほど速度が高くなり，かつ事故率も増加 することを実証している．したがって偏差角は，アメリ カのfastest pathによる推定速度に代わる評価指標であると も言える.

このように，幾何構造条件から推定される速度を根拠 として幾何構造設計を評価する考え方は，合理的な方法 の一つである. しかし, 幾何構造が安全性能に与える影 響を速度のみで表現するには限界がある，例えば，流入 部接続角度(図-6参照)を小さくすれば，流入車両と環道 車両が仮に衝突したとしても車両同士の交錯する角度が 小さく，通常の十字交差点で発生するような出合い頭や 右折対直進事故などの致命的な事故は起こり得ない.し かし一方で，流入部接続角度が小さいことで流入車両は 環道車両を視認しにくくなるため, 軽微な事故の回数は 増加することが想定されるし，合流しやすいため速度が 高くなることも考えられる。このように，衝突が起きに くい幾何構造にすることと，仮に衝突が発生してもその 重度が小さいことは必ずしも両立するものとは限らない 幾何構造設計においてはこの両面のバランスに配慮する ことが重要であるが，このような観点に立った幾何構造 設計の判断基準や評価指標については海外諸国において も検討されていない.

\section{3. リスクの概念に基づく安全性能代理指標の導 入}

\section{（1）安全性能代理指標}

安全性能を評価する最も一般的でわかりやすい方法は, 事故件数や事故率などのように，事故として顕在化した 危険事象の発生回数や発生割合で評価することである. しかし，事故の発生は稀な事象であり，信頼性のある評 価モデルを構築するためには，多くの箇所かつ長い期間 の事故データが必要亡なる，わが国では，ラウンドアバ ウトの導入経験は未だ少なく事故に関するデータはほと んど蓄積されていないため，海外のような事故率を予測 するようなモデルを構築することは極めて困難である. これに対して，顕在化した事故そのものを予測するので 
はなく，事故に繋がりか祄ない潜在的な危険事象の発生 頻度などを代理指標として予測することで, 安全性能を 評価しようとする手法も考えられる。このような指標は 安全性能代理指標(surrogate safety measure, 以下SSM) と呼 ばれており，これまでの既往研究においても様々なSSM が用いられている. 主なものとして, 例えばGuido et al. ${ }^{10}$ は, TTC (time to collision)やPET (post encroaching time)といっ た交錯指標を用いてラウンドアバウトの評価を行ってお り, Mussone ${ }^{11)}$ は, 視認性の観点からラウンドアバウト の幾何構造を評価している. Gettman and $\left.\mathrm{Head}^{12}\right)$ は, これ らのほかにも速度や交錯点のばらつきなどもSSMとして 用いられることがあると述べている．前章でレビューし たアメリカやスイスの評価方法は速度をSSM の一つと 捉えたものであると解釈できる.

このように，何らかのSSMを用いて安全性能を評価す ることは，事故に関するデータがほとんど蓄積されてい ないわが国において有効な手段であると考えられる。し かし既往研究の中で用いられたSSMでは，前章で述べた ような幾何構造設計において重視すべき衝突の起きやす さと衝突したときの損失の両面を考慮した指標とはなっ ていない. 本研究ではこのような問題認識を踏まえ, 新 たなSSMの導入を検討する.

\section{(2) 本研究におけるリスク指標の定義}

新たなSSMを検討するにあたり，改めて「安全性能」 の本質的な意味について考える. そもそも「安全」とは, 様々な分野においてその定義や捉え方は異なってくるが, 国際基本安全規格(ISO/IEC) ${ }^{13)}$ においては，「許容できな いリスクがないこと」と定義されている. この定義を踏 襲すると, 幾何構造設計における安全性能とは「リスク がある一定水準以下に抑制できる幾何構造となっている か」と解釈することができる．この「リスク」について も様々な定義が存在するが，同規格においては，「危害 の発生確率及びその危害の程度の組合せ」とされており, 一般的に期待值としてこれらの積で表現される，交通工 学の分野でリスクについて扱った研究として, 吉井ら ${ }^{14}$ の事故リスクの考え方があるが，これは統計的なデータ から推定される「事故の起こりやすさ」を示寸概念であ る. 蓮花 ${ }^{15}$ は, 交通心理学におけるリスクテイキングの 考え方において, リスクは「事故発生の可能性はどの程 度高いか」という定量的な概念であり，リスクに似た概 念としてハザードは「どのような条件・対象が事故を招 くか」という定性的な概念であると述べている。この関 係について若林ら19は，交通上危険な場所(=ハザード)に おいて，危険なコンフリクト(=リスク)が生じることで 事故が発生するという解釈をしている. リスクの考え方 を援用した研究例として，鈴木ら における左折車と横断歩行者の交錯事象に対してリスク
事象の発生確率とその損失強度の積(=期待值)で表され る指標を導入し，信号交差点の運用方法を評価したもの や，中村・馬㴊18のように交錯の危険性と期待遅れの組 合せからラウンドアバウトと信号交差点の性能を比較評 価したものがある.

本研究においても, 期待值として算出される物理量を リスクと捉えることとし，衝突の起きやすさを危害の発 生確率, 仮に衝突したときの重度を危害の程度として扱 うことで表現する. 危害の発生確率と幾何構造条件の関 係については，本来は事故データをもとに検討すべきで あるが，十分な事故の実績データが存在しない現状にお いては，その関係を定式化することは困難である．幾何 構造設計を考える上では, 流入車両から環道車両を十分 に視認できることが安全性能を確保するうえで最も重要 な事項の一つであると考えられることから, 流入車両が 環道に流入する際に環道車両を見落とす確率(見落とし 確率)を危害の発生確率と置き換え，これを幾何構造か ら推定することを考える，危害の程度については，衝突 時の運動エネルギー損失量を衝突時の強度に置き換えた Alhajaseen ${ }^{199}$ の考え方を適用し，これが危害の程度に相当 すると考える.

以上より, 本研究におけるリスク指標を, 以下の式 (1)として定義する.

$$
R I=P_{\text {miss }} \times I_{c r s}
$$

ここに, $R I$ : リスク指標(Risk Index), $P_{\text {mis }}$ : 見落とし確 率, Ias: 衝突強度である.

リスク指標の要素である見落とし確率と衝突強度を算 出寸るためには, 与えられた幾何構造条件から流入車両 と環道車両が交錯する位置(交錯位置)を推定し, さらに 交錯位置を通過する際の速度と交錯位置に至るまでの軌 跡を推定することが必要となる，なお，本論文において は幾何構造設計の評価に用いることを念頭にしているこ とから, 安全性を考える上で重要な直進方向に走行する 車両同士の衝突を扱うものとする，次章以降では，各種 幾何構造条件を説明変数とした走行挙動推定モデルを検 討し, リスク指標を算出寸るまでの方法について述べる.

\section{4. 車両挙動モデリング}

\section{（1） 走行軌跡の再現}

ラウンドアバウトを通過する際には，一般に $\mathrm{S}$ 字の走 行軌跡が生じる. 本研究では, その走行軌跡を直線・ク ロソイド・円弧の組合せとして表現する．これは，ステ アリングの操作を示す曲率の值が走行距離に対して線形 に変化することと同值である. このように，曲率パラメ 一タに基づいて走行軌跡を推定する方法は，例えば Alhajyaseen, et al. ${ }^{20)}$ の信号交差点における右左折車両の 

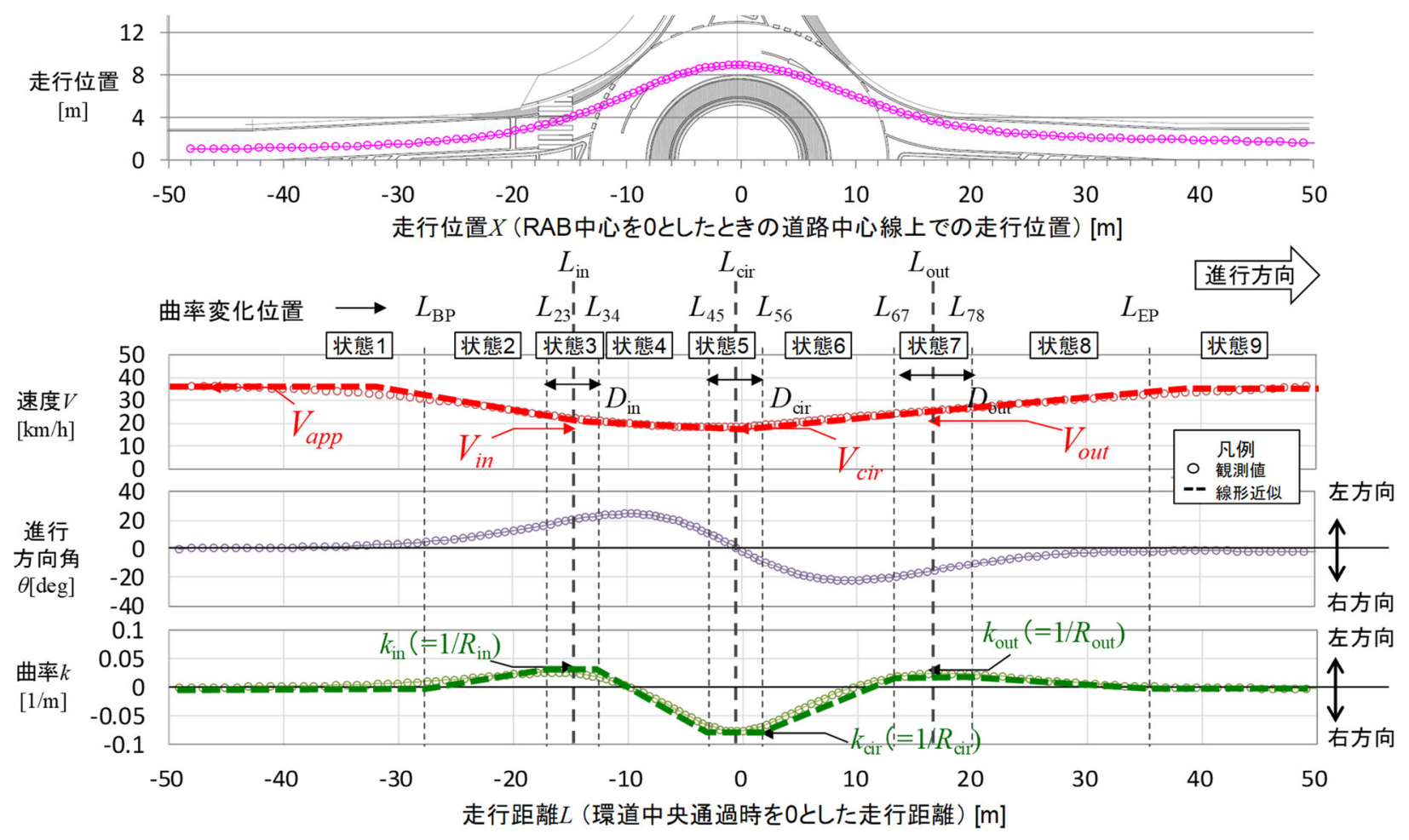

図-1 走行挙動プロファイルの例と走行挙動パラメータ

表-1 走行挙動調査箇所

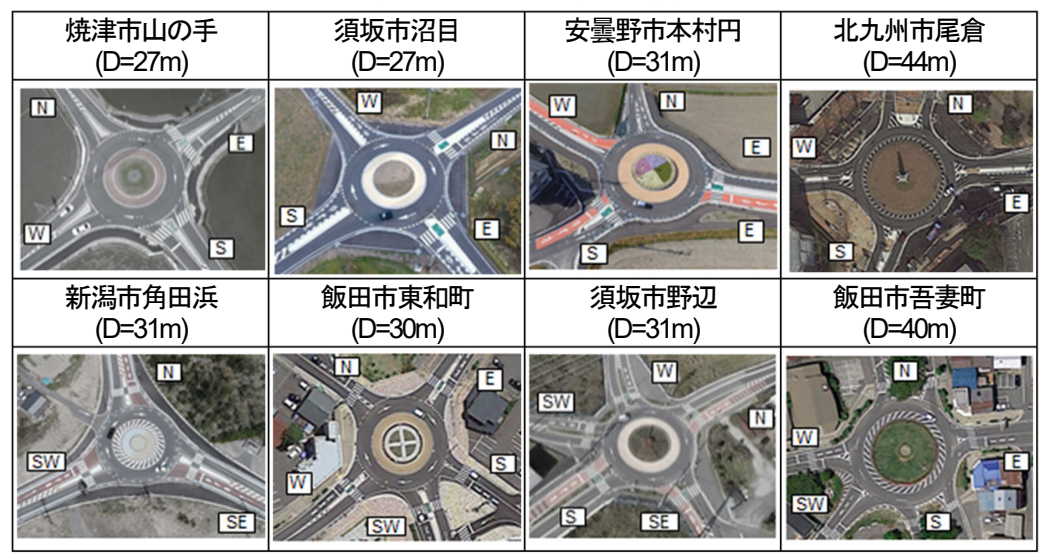

表-2 調査対象箇所の幾何構造諸元

\begin{tabular}{|c|c|}
\hline 幾何構造要素 & 諸元範囲 \\
\hline 枝数 & $3-5$ \\
\hline 外径[m] & $27-44$ \\
\hline 流出入部間交差角度 $[\mathrm{deg}]$ & $110-250$ \\
\hline $\begin{array}{c}\text { 環道幅員[m] } \\
\text { (段差無しエプロ部を含む) }\end{array}$ & $4.5-6.0$ \\
\hline エプロン段差 & あり-なし \\
\hline 流入部幅員 $[\mathrm{m}]$ & $2.5-3.1$ \\
\hline 流入隅角部曲線半径 $[\mathrm{m}]$ & $5-30$ \\
\hline 流入分離島幅 $[\mathrm{m}]$ & $0-3.0$ \\
\hline 流入部分離島長さ $[\mathrm{m}]$ & $0-30$ \\
\hline 流出部幅員 $[\mathrm{m}]$ & $2.7-4.0$ \\
\hline 流出隅角部曲線半径 $[\mathrm{m}]$ & $3-40$ \\
\hline 流出分離島幅 $[\mathrm{m}]$ & $0-3.0$ \\
\hline
\end{tabular}

走行軌跡の推定においても用いられた手法であるが，ラ ウンドアバウトにおける曲率の変化は通常の右左折と比 較して複雑となるため, 推定に必要なパラメータが多い ことが異なる．図-1は，焼津市山の手ラウンドアバウト (表-1参照)において観測された走行挙動データの一例で ある. このとき, 曲率の変化を線形要素の組合せとして 表現とすると, 式(2)に示すように9段階で走行状態別に 定式化することができる. 式(2)中の曲率の変化位置L や 曲率kiは，走行軌跡に関するパラメータとして定義する.

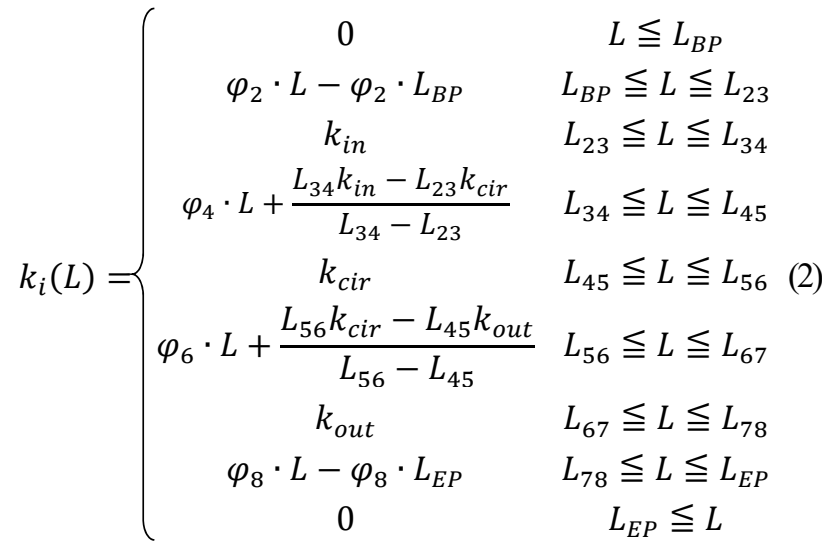

ここに, $k_{i}$ : 走行状態 $l$ における曲率, $L:$ 走行距離(ラ ウンドアバウトの環道中央断面通過時を 0 とし, 進行方 
表-3 走行軌跡に関するパラメータの推定結果

※()内は $\mathrm{t}$ 値を表す

\begin{tabular}{|c|c|c|c|c|c|c|c|c|}
\hline \multirow[b]{2}{*}{ 幾何構造要素 } & \multicolumn{5}{|c|}{ 曲率変化位置パラメータ } & \multicolumn{3}{|c|}{ 曲率パラメータ } \\
\hline & $\begin{array}{c}\text { ステアリング } \\
\text { 開始位置 } \\
L_{\mathrm{BP}} \\
\end{array}$ & $\begin{array}{c}\text { 流入部曲率 } \\
\text { 最大位置 } \\
L_{\mathrm{n}} \\
\end{array}$ & $\begin{array}{c}\text { 環道内曲率 } \\
\text { 取大位置 } \\
L_{\dot{\alpha}}\end{array}$ & $\begin{array}{c}\text { 流出部曲率 } \\
\text { 最大位置 } \\
L_{\text {at }}\end{array}$ & $\begin{array}{c}\text { ステアリング } \\
\text { 終了位置 } \\
L_{E P}\end{array}$ & $\begin{array}{c}\text { 流入部 } \\
\text { 曲率最大値 } \\
k_{n}\end{array}$ & $\begin{array}{c}\text { 環道内 } \\
\text { 曲率最小值 } \\
k_{\dot{\alpha}}\end{array}$ & $\begin{array}{c}\text { 流出部 } \\
\text { 曲率最大値 } \\
k_{a t}\end{array}$ \\
\hline 定数項 & $\begin{array}{r}5.05 \\
(1.04)\end{array}$ & $\begin{array}{r}-30.72 \\
(-1.49)\end{array}$ & $\begin{array}{r}-5.46 \\
(-0.91)\end{array}$ & $\begin{array}{r}-101.84 \\
(-10.4)\end{array}$ & $\begin{array}{r}32.5 \\
(2.05)\end{array}$ & $\begin{array}{r}-2.20 \times 10^{2} \\
(-0.49)\end{array}$ & $\begin{array}{r}-2.60 \times 10^{2} \\
(-2.63)\end{array}$ & $\begin{array}{r}5.71 \times 10^{2} \\
(1.21)\end{array}$ \\
\hline 外径 [m] & $\begin{array}{r}-1.89 \\
(-2.99) \\
\end{array}$ & $\begin{array}{r}-2.70 \times 10^{-1} \\
(-1.97) \\
\end{array}$ & - & $\begin{array}{r}5.39 \times 10^{-1} \\
(17.1) \\
\end{array}$ & - & $\begin{array}{r}2.18 \times 10^{-3} \\
(4.18) \\
\end{array}$ & $\begin{array}{r}1.80 \times 10^{-3} \\
(2.06) \\
\end{array}$ & - \\
\hline $\begin{array}{l}\text { 流出入部間 } \\
\text { 交差角度 }[\mathrm{deg}]\end{array}$ & $\begin{array}{r}-8.97 \times 10^{2} \\
(-7.63)\end{array}$ & $\begin{array}{r}-9.68 \times 10^{2} \\
(-10.1)\end{array}$ & $\begin{array}{r}1.10 \times 10^{-2} \\
(2.43)\end{array}$ & $\begin{array}{r}4.82 \times 10^{2} \\
(1.86)\end{array}$ & $\begin{array}{r}5.23 \times 10^{2} \\
(3.01)\end{array}$ & - & $\begin{array}{r}-9.23 \times 10^{4} \\
(-12.7)\end{array}$ & $\begin{array}{r}9.35 \times 10^{5} \\
(2.41)\end{array}$ \\
\hline $\begin{array}{c}\text { 環道幅員 }[\mathrm{m}] \\
\text { (段差無しエプロン含む) }\end{array}$ & - & $\begin{array}{r}8.73 \\
(2.15) \\
\end{array}$ & - & $\begin{array}{r}14.5 \\
(2.09)\end{array}$ & - & - & $\begin{array}{r}6.22 \times 10^{-2} \\
(3.33) \\
\end{array}$ & - \\
\hline $\begin{array}{l}\text { 流入部隅角部 } \\
\text { 開始位置 }[\mathrm{m}] \\
\end{array}$ & $\begin{array}{r}-2.42 \\
(-2.34) \\
\end{array}$ & - & - & - & - & - & - & - \\
\hline $\begin{array}{c}\text { 流入部幅員 } \\
{[\mathrm{m}]}\end{array}$ & - & - & - & - & - & - & - & - \\
\hline $\begin{array}{l}\text { 流入隅角部 } \\
\text { 曲線半径 [m] }\end{array}$ & $\begin{array}{r}-1.20 \\
(-2.34) \\
\end{array}$ & $\begin{array}{r}-6.30 \times 10^{2} \\
(-2.79) \\
\end{array}$ & - & - & - & $\begin{array}{r}-1.61 \times 10^{4} \\
(-6.77) \\
\end{array}$ & - & - \\
\hline $\begin{array}{c}\text { 流入部分離島長さ } \\
{[\mathrm{m}]}\end{array}$ & - & - & - & - & - & $\begin{array}{r}1.16 \times 10^{2} \\
(4.19) \\
\end{array}$ & - & - \\
\hline $\begin{array}{c}\text { 流出部幅員 } \\
{[\mathrm{m}]}\end{array}$ & - & - & - & - & - & $\begin{array}{r}-9.59 \times 10^{4} \\
(-2.99) \\
\end{array}$ & - & - \\
\hline $\begin{array}{l}\text { 流出隅角部 } \\
\text { 曲線半径[m] }\end{array}$ & - & - & - & $\begin{array}{r}-2.60 \times 10^{-1} \\
(-2.71) \\
\end{array}$ & - & - & - & $\begin{array}{r}-9.07 \times 10^{-3} \\
(-5.70) \\
\end{array}$ \\
\hline $\begin{array}{c}\text { 流出分離島幅 } \\
{[\mathrm{m}]}\end{array}$ & - & - & - & - & - & - & - & $\begin{array}{r}-7.40 \times 10^{4} \\
(-1.85) \\
\end{array}$ \\
\hline $\begin{array}{l}\text { 流出隅角部 } \\
\text { 開始位置[m] }\end{array}$ & - & - & - & - & $\begin{array}{r}4.57 \times 10^{-2} \\
(3.55) \\
\end{array}$ & - & - & - \\
\hline 自由度調整済み $\mathrm{R}^{2}$ & 0.73 & 0.79 & 0.27 & 0.49 & 0.43 & 0.73 & 0.86 & 0.69 \\
\hline サンプル数 & & & & 3 & & & & \\
\hline
\end{tabular}

向を正とした距離)， $L_{i j}$ : 走行状態加ら $j$ へ変化する位置, $k_{i n}, k_{\text {or }}, k_{\text {out }}$ は流入部，環道部，流出部に発生する曲率 の極值である．また， $\varphi_{2}, \varphi_{4}, \varphi_{6}, \varphi_{8}$ は曲率の変化率であり， 例えば走行状態 4 における $\varphi_{4}$ は, 一定の曲率変化を仮定 するため, 式(3)で表される.

$$
\varphi_{4}=\frac{k_{c i r}-k_{i n}}{L_{45}-L_{34}}
$$

さらに，流入部・環道部・流出部の曲率最大位置 $\left(L_{i n,}\right.$ L crir, Lout) は，軌跡の曲率が一定である円弧走行区間の中間 点と定義し，例えば流入部の曲率最大位置Link，以下の 式(4)により算出される.

$$
L_{i n}=\frac{L_{23}+L_{34}}{2}
$$

ここに, $L_{\text {in }}$ : 流入部曲率最大位置 $[\mathrm{m}]$ である.

以上の走行軌跡パラメータが決定されれば，境界部での 走行位置，進行方向角に関寸る制約条件を与えることで, 式(2)で示される曲率変化の2回積分として走行軌跡が推 定される.

\section{(2) パラメータ推定結果}

(1)の走行軌跡に関するパラメータと幾何構造との関 係を把握するため，表-1および表-2に示す国内8箇所の ラウンドアバウトの 30 進行方向について走行挙動調査 を実施し，得られた走行挙動データから重回帰分析によ

り表-3に示すパラメータを推定した。
表-3によると，まず外径や流出入部間交差角度につい ては，流入から流出までのほとんどの走行軌跡に関する パラメータに対して有意であり，走行軌跡に影響の大き い幾何構造要素であると言える。このうち流入部曲率最 大位置に着目すると，推定された係数值はいずれも符号 が負になっている，これは，外径や交差角度が大きいほ ど流入時のステアリング操作位置がラウンドアバウトか ら遠いことを意味しており，外径や交差角度が大きいと ラウンドアバウトを周回する際の走行距離が増えるため である．次に，曲率最大值について見ると，流入部・流 出部については隅角部の曲線半径が，環道内については 流出入部間交差角度が影響の大きい幾何構造要素である ことがわかる。

\section{(3) 走行速度の再現}

走行速度の再現については，アメリカの軌跡に基づく 速度の推定方法の考え方を適用し，図-1に示寸曲率が極 值を取る流入部 $L_{i n}$, 環道内 $L_{\text {cir }}$, 流出部 $L_{\text {out }}$ の3地点におけ る速度 $V_{i r}, V_{c i r}, V_{\text {out }}$ を曲率(曲線半径の逆数)から推定し, こ れら3地点の速度とアプローチ速度 $V_{a p p}$ (単路の自由走行 速度)の間は等加速度を仮定して便宜的に直線で補間し た速度プロファイルを仮定する.

図-2は，挙動調査により得られた流入部ごとの軌跡の 曲線半径の平均值と速度の85パーセンタイル值の関係を プロットし，アメリカの推定モデルと比較したものであ 
る.これを見ると，とくに曲線半径が大きい領域におい てアメリカの推定モデルに対して乘離が見られる。 そこ で, 本研究での調査結果を用いて, 最小二乗法によりア メリカのモデル式のパラメータを改良して得られた以下 の式(5)に基づき，速度を推定する。

$$
V_{i}=13.965 \cdot R_{i}^{0.1839}
$$

ここに, $V_{i}$ : 予測速度の85パーセンタイル值 $[\mathrm{km} / \mathrm{h}]$,

$R_{i}$ : 軌跡の曲線半径 $\left(=1 / k_{i}\right)[\mathrm{m}]$ である.

モデル式の適合度を示す平均二乗誤差(RMSE)は，パ

ラメータ改良前の $4.8 \mathrm{~km} / \mathrm{h}$ 吅改良後は $1.8 \mathrm{~km} / \mathrm{h}$ に減少し た.

なお，流出入部のアプローチ速度との間は，減速度を $2.0 \mathrm{~m} / \mathrm{sec}^{2}$, 加速度を $1.5 \mathrm{~m} / \mathrm{sec}^{2}$ と設定し，同様に直線補間 することで速度プロファイルを得ることとする.

\section{5. リスク指標の算出}

\section{（1）見落とし確率の算出}

流入車両が環道車両を見落とすことで出合い頭に衝突 する事象は，流入車両と環道車両が同時に交錯位置を通 過する条件のもと, 流入車両が全く回避行動をとらずに 流入した場合に発生し得る.ここで, 流入車両と環道車 両が同じ時刻 $(t=0)$ に交錯位置を通過する状況を考える. 衝突時より秒前に遡った時刻林いて流入車両が環道 車両を視認できない条件は，流入車両から見た環道車両 の存在する方向角 $\theta_{g t l}$ 対して, 流入車両ドライバーの 有効視野角 $\theta_{\text {fov }}$ が小さい場合，すなわち以下の式(6)に示 す条件が成り立つ場合である。

$$
\theta_{\text {fov }}<\theta_{c f t}(t)
$$

ここに, $\theta_{\text {fov }}$ : 流入車両ドライバーの有効視野角[deg], $\theta_{g t t}$ : 流入車両から見た環道車両の存在する方向角 $[\mathrm{deg}]$ で ある.

なお，流入車両のドライバーは流入する際に安全確認 のために視線移動や首振りを行うのが通常であるが，一 定割合でこのような安全確認行動を怠ることが発生する と考えると，仮にこのような安全確認行動をとらなくと も流入車両が自然に環道車両を認知できる幾何構造設計 の方が視認性の観点からは望ましい，そこで，本研究で は視線移動や首振りなどの安全確認行動は考えないこと とした.

運転時の有効視野角については多くの既往研究におい て調査されており, 高齢者と若年者など運転者によって 比較したもの, 走行速度や混雑度など交通状況別に比較 したものなどがある．そのため有効視野角を一律に決め ることは難しく, 首振り角度と同様に今後検証が必要で あると考えられる. 本研究では, 既往研究の中において も様々な被験者属性での実験を実施している森島ら211の

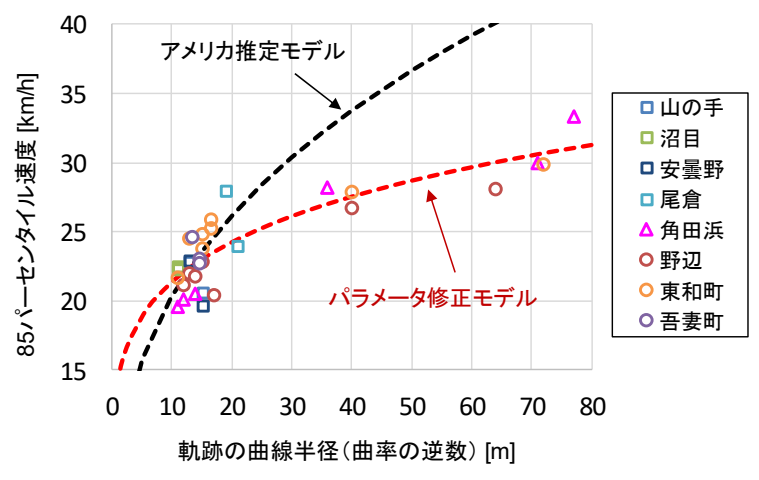

図-2 速度推定モデルの検証

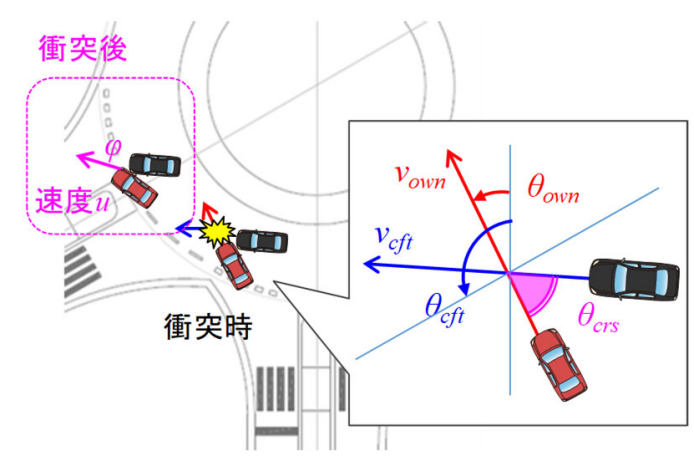

図-3 衝突時・衝突後の走行挙動

研究成果を参照するものとし，有效視野角は個人差を考 慮した正規分布を仮定し，平均值は38deg，標準偏差は 10degと設定することとした.

以上の仮説より，有効視野角について正規分布を仮定 した場合の，ある時刻たおける環道車両を視認できな い確率 $P(t)$ は以下の式(7)となる.

$$
P(t)=\int_{\theta_{c f t}}^{\infty} \frac{1}{\sqrt{2 \pi}} \exp \left\{-\frac{\left(\theta_{f o v}-\mu\right)^{2}}{2 \sigma^{2}}\right\} d \theta
$$

ここに, $\mu$ : 有効視野角の平均值 $(=38[\mathrm{deg}]), \sigma$ : 有効視野 角の標準偏差 $(=10[\mathrm{deg}])$ である.

ここまでは，衝突前のある瞬間の時刻について考えた が，実際にはある一定区間(または時間)の中で安全確認 を行い, この中で環道車両を認識できれば衝突を回避で きる．言い換えれば，最終的に見落としが発生するのは， 流入車両が安全確認を開始する時刻祅から衝突に至るま での限界反応時刻 $t_{\text {re }}$ 間に, 流入車両が環道車両を一度 も視認できない状態が続いた場合である.したがって, ある車両 $i の$ 見落とし確率 $P_{\text {mis }}$ は, $P(t)$ のt 時生起確率であり, 式(8)のように算出される.

$$
P_{\text {miss }}=\prod_{t_{s t}}^{t_{r e}} P(t)
$$

ここに, $P_{\text {mis }}$ : 見落とし確率, $t_{s t}$ : 流入車両の安全確 認の開始時刻[秒], tre : 衝突を回避するための限界反応 時間 $($ tre $)(=0.7$ 秒)である.

安全確認の開始時刻は, 環道に流入する手前 $10 \mathrm{~m} に$ 到 


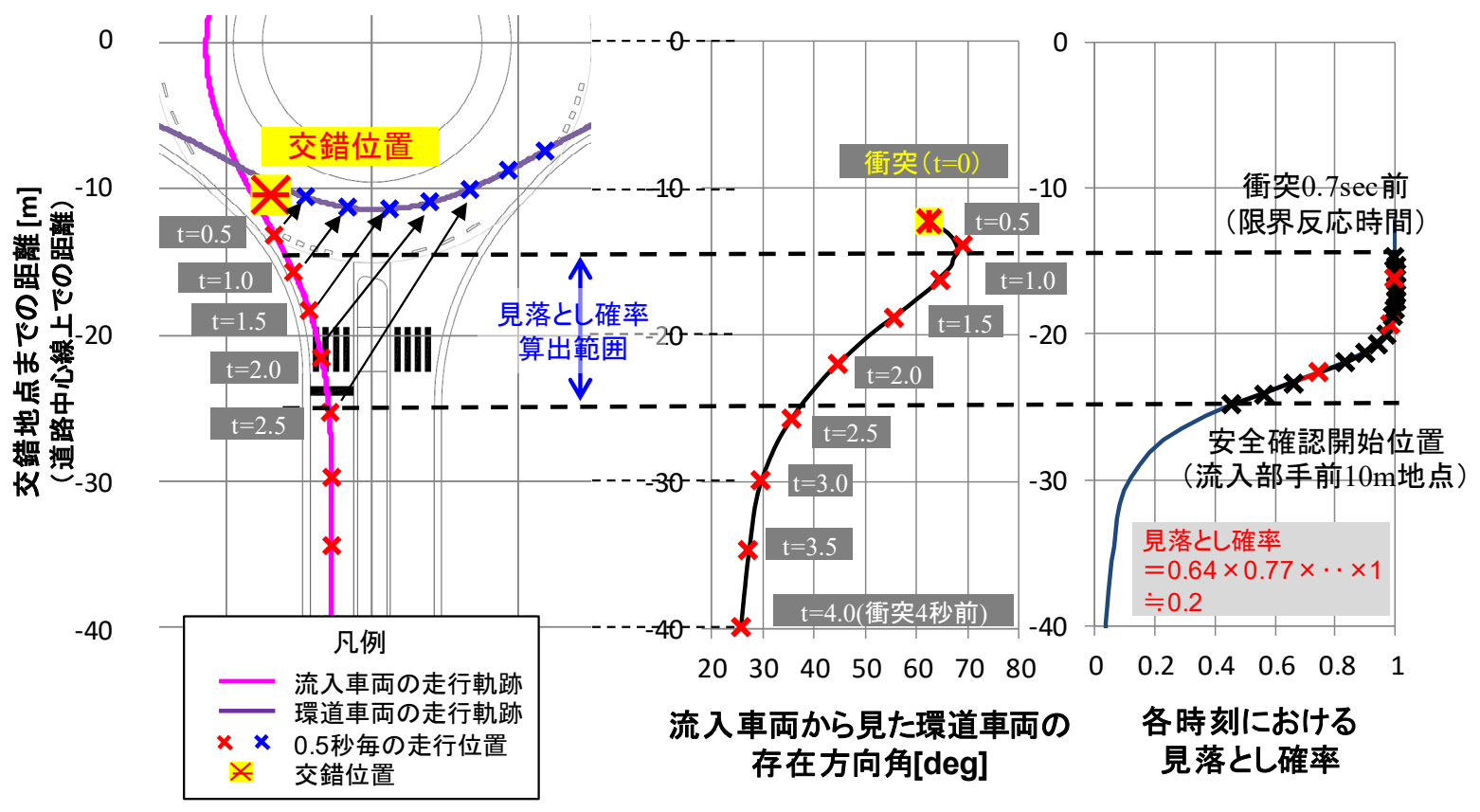

図-4 標準的な幾何構造条件における走行挙動と見落とし確率の算出結果

達した時間とした。 これは, 流入部に横断歩道が設置さ れる場合の停止線位置に相当し，他の流入部に対する視 認性の確保が必要となる位置である。また限界反応時間 は一般的に知られる 0.7 秒とし，ブレーキが間に合わな くても何らかの回避行動により出合い頭に衝突すること を回避するための限界值と考えた．また，時刻 $t$ の刻み 幅(スキャン時間)については, 人間の認知, 判断プロセ スの周期と考えられる0.1秒間隔とした.

\section{（2）衝突強度の算出}

流入車両と環道車両が衝突する際のエネルギー損失量 として算出する衝突強度は, 衝突前後における運動量の 保存則および運動エネルギーの保存則から求める. 衝突 後の運動状態は両車両の速度と進行方向の合わせて4つ の未知数となるが, 図-3に示すように衝突後は両車両が 一体となって動く，つまり完全非弾性衝突を仮定すれば 未知数は 2 つなり, 以下の式(9)の運動エネルギ一保存 則および式(10), (11)の運動量保存則より, エネルギーの 損失分が算出可能となる.

$$
\begin{gathered}
\frac{1}{2} m_{\text {own }} v_{\text {own }}{ }^{2}+\frac{1}{2} m_{c f t} v_{c f t}{ }^{2} \\
=\frac{1}{2}\left(m_{\text {own }}+m_{c f t}\right) u^{2}+\Delta K e \\
m_{\text {own }} v_{\text {own }} \\
\cos \theta_{\text {own }}+m_{c f t} v_{c f t} \cos \theta_{c f t} \\
=\left(m_{\text {own }}+m_{c f t}\right) u \cos \varphi \\
m_{\text {own }} v_{\text {own }} \sin \theta_{\text {own }}+m_{c f t} v_{c f t} \sin \theta_{c f t} \\
=\left(m_{\text {own }}+m_{c f t}\right) u \sin \varphi
\end{gathered}
$$

ここに, $m_{\text {own }}$ : 流入車両の車両重量 $[\mathrm{kg}], m_{g t}$ : 環道車 両の車両重量 $[\mathrm{kg}], v_{o w n}$ : 流入車両の速度 $[\mathrm{km} / \mathrm{h}], v_{g t}$ : 環
道車両の速度 $[\mathrm{km} / \mathrm{h}], u$ : 衝突後の速度 $[\mathrm{km} / \mathrm{h}], \Delta K_{e}$ : エネ ルギーの損失量, $\theta_{\text {own }}$ : 流入車両の衝突時の進行方向角 [deg], $\theta_{g t t}$ : 環道車両の衝突時の進行方向角[deg], $\varphi$ : 衝 突後一体となって動くときの進行方向角[deg]である.

衝突強度は幾何構造の評価を目的とすることから, 車 両重量の影響を除いた単位重量あたりの強度, 寸なわち $m_{o w n}=m_{g t}=1$ として考える. さらに, 進行方向角 $\theta$ は道路 中心線に対寸る方向角で定義しているが，交錯時の流入 車両の進行方向を基準とした角度で考えると $\theta_{\text {own }}=0, \theta_{g t}$ $=\theta_{a x}$ (交錯角度) と置き換えられることから, 最終的に衝 突強度Iasは以下の式(12)として得られる。

$$
\begin{aligned}
I_{c r s}= & \Delta K e=\frac{1}{4} v_{o w n}{ }^{2}+\frac{1}{4} v_{c f t}{ }^{2} \\
& -\frac{v_{o w n} \cdot v_{c f t} \cdot \cos \theta_{c r s}}{2}
\end{aligned}
$$

ここに， $\theta_{a s}:$ 交錯時の車両間の交錯角度 $[\mathrm{deg}]$ である. 上式より, 衝突強度はそれぞれの流入車両, 環道車両 の速度の2乗項と, 両車両の速度と交錯角度の積からな る項で構成され，速度が高いほど，さらには交錯角度が 180degに近いほど衝突強度が高くなることを表している.

\section{（3）標準的な幾何構造におけるリスク指標算出例}

図-4は，表-4に示す正十字の標準的な幾何構造を有寸 るラウンドアバウトにおいて, 走行軌跡の再現結果と交 錯位置，さらに衝突に至るまでの環道車両の存在方向角， 見落とし確率を推定した例を示したものである.これに よると，交錯位置は流入車両が環道に流入した直後に位 置しており, 出合い頭事故の状況を再現しているものと 考えられる. なお交錯位置が軌跡からずれているのは, 車両幅 $(1.8 \mathrm{~m})$ を考慮して交錯位置を算出しているためで 


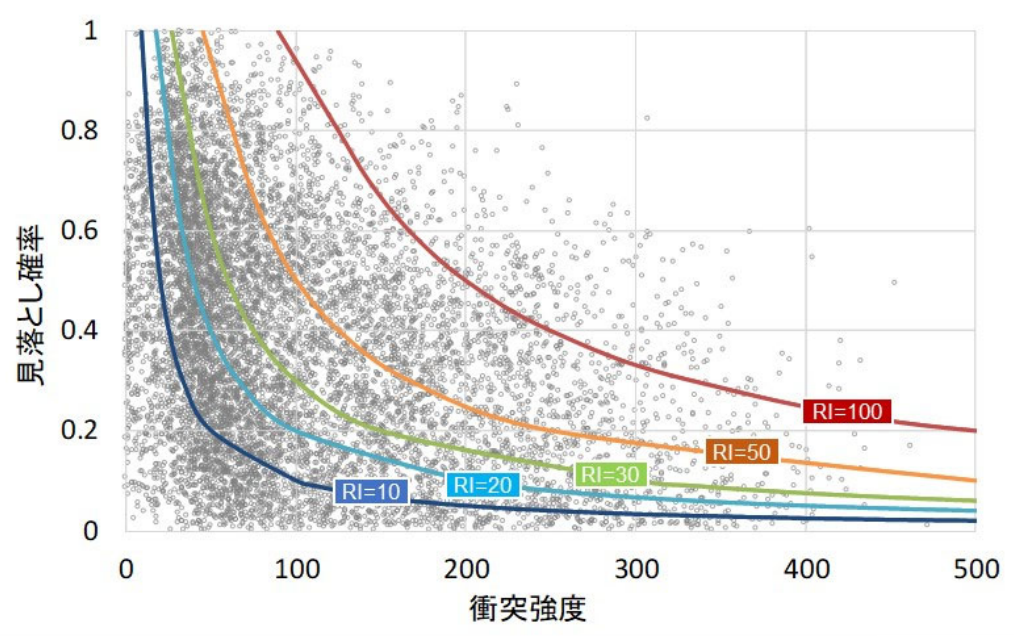

表-4 標淮的な幾何構造条件

\begin{tabular}{|c|c|c|}
\hline 幾何構造要素 & $\begin{array}{c}\text { 構造 } \\
\text { 条件 }\end{array}$ & $\begin{array}{c}\text { SIM } \\
\text { 範囲 }\end{array}$ \\
\hline 流出入部間交差角度 $[\mathrm{deg}]$ & 180 & $110-250$ \\
\hline 上流隣接角 $[\mathrm{deg}]$ & 90 & $45-135$ \\
\hline 下流隣接角 $[\mathrm{deg}]$ & 90 & $45-135$ \\
\hline 外径 $[\mathrm{m}]$ & 30 & $20-50$ \\
\hline 環道幅員 $[\mathrm{m}]$ & 5.0 & $3.0-8.0$ \\
\hline $\begin{array}{c}\text { エプロン幅員 }[\mathrm{m}] \\
\text { (段差有無) }\end{array}$ & 2.0 & $0-5.0$ \\
(あり) & \\
\hline 流入部幅員 $[\mathrm{m}]$ & 3.0 & $2.5-4.0$ \\
\hline 流入隅角部曲線半径 $[\mathrm{m}]$ & 15 & $5-50$ \\
\hline 分離島幅 $[\mathrm{m}]$ & 2.0 & $0-4.0$ \\
\hline 流出部幅員 $[\mathrm{m}]$ & 3.0 & $2.5-4.0$ \\
\hline 流出隅角部曲線半径 $[\mathrm{m}]$ & 15 & $5-50$ \\
\hline
\end{tabular}

図-5＼cjkstart見落とし確率と衝突強度の関係

ある．交錯位置から限界反応時間である0.7秒前の地点 は，およそ流入部のゆずれ線位置に相当しており，さら に流入部から手前 $10 \mathrm{~m} の$ 地点はおよそ 2.5 秒前に相当して おり，この区間における環道車両との位置関係が見落と し確率の算出結果に影響することになる.

\section{6. リスク指標推定モデルの構築}

\section{(1) 数值シミュレーション}

前章の方法により算出される見落とし確率や衝突強度 は，様々な幾何構造要素の条件を変更することでその算 出結果は複雑に変化する。このような複雑な関係を理論 式として表現することは極めて困難である，そこで，数 值シミュレーションにより様々な幾何構造条件における リスク指標を算出し，この結果から幾何構造との関係を 回帰モデルとして表現することを考える.

数值シミュレーションにおいて考慮する幾何構造条件 は表-4の通りである. 各幾何構造要素にランダムな諸元 值をもった20,000通りの幾何構造条件において，各々の 幾何構造に対して推定された流入車両およひ環道車両の 走行軌跡と速度から流入車両が流入した際に環道車両と 衝突する状況を想定し, 双方の車両の走行挙動を推定す ることで見落とし確率，衝突強度を算出寸る. 各幾何構 造要素はそれぞれ独立であることを前提としているが, ランダムに決められた数值で図面を作成すると，外径と 流出入部の隅角部曲線半径のバランスによってはうまく 流出入部が外径に擦りつかないケースが生じ得る。この ようなケースについては, 数值シミュレーションの対象 外としている.

\section{(2) 数值シミュレーション結果}

図-5は20,000通りの幾何構造条件について，数值シミ ユレーションにより算出された見落とし確率と衝突強度

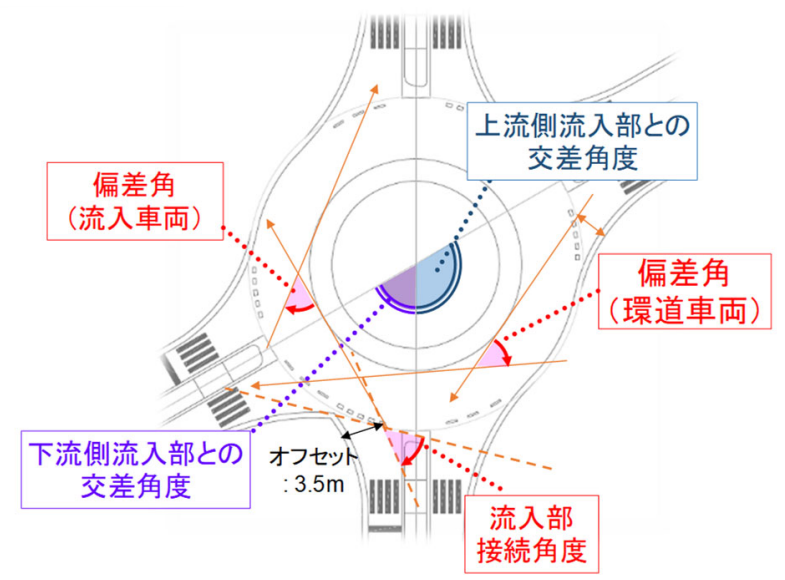

図-6 モデル式で考慮する幾何構造

の関係をプロットしたものである．なお図中に色別で示 されるラインは，リスク值(RI)が10，20，30，50，100に 相当するコンターを示している. リスク值は見落とし確 率と衝突強度の積であるため, グラフ中の右上ほどリス ク值は高く, 左下ほどリスク值は小さいことになる.

見落とし確率と衝突強度は，全体的な傾向として見落 とし確率が高、場合には衝突強度が小さく, 逆に衝突強 度が高い場合には見落とし確率が低いといったように, 見落とし確率と衝突強度は相反関係の傾向がある.これ は，合流に近い形状とすることで衝突の程度は軽減され る一方，環道車両に対しては見落としやすくなることを 示寸結果である.

\section{(3) リスク指標推定モデル式の検討}

数值シミュレーションの結果を踏まえて, 幾何構造条 件から直接リスク值を算出するためのモデル化を検討寸 る.リスク值の要素である見落とし確率と衝突強度には 相関性は認められないため, 見落とし確率と衝突強度の 積であるリスク值を直接モデル化しようとすると，各幾 何構造要素との関係が埋没してしまう。 そうすると，例 えばリスク值が高く不適切な幾何構造であると判断され る場合，見落とし確率を低減させるべきか，あるいは衝 

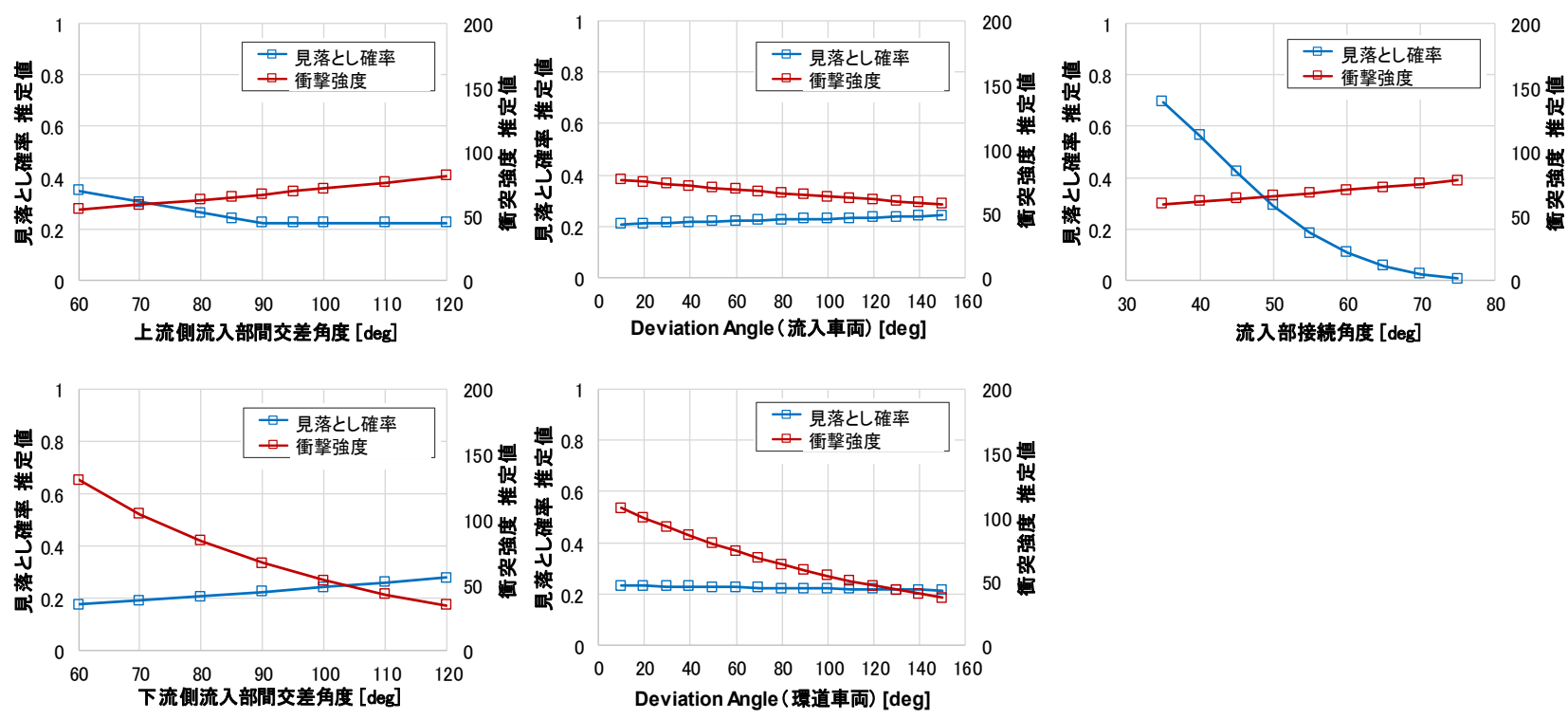

図-7 各幾何構造要素の感度分析

突強度を低減させるべきか判断できない，そのため，見 落とし確率と衝突強度のそれぞれに対してモデル化する. 幾何構造から決定される評価関数 $V(x)$ に応じて，見落と し確率は，0から1の範囲の成長曲線，衝突強度は累乗曲 線を仮定した以下の式(13)，(14)によりそれぞれモデル化 する.

$$
\begin{gathered}
P_{\text {miss }}=\frac{1-\exp \left\{b_{2} \cdot V(x)\right\}}{1+b_{1} \cdot \exp \left\{b_{2} \cdot V(x)\right\}} \\
=\frac{1-\exp \left\{b_{2} \cdot\left(\sum_{i}^{n} a_{i} \cdot x_{i}+\text { const }\right)\right\}}{1+b_{1} \cdot \exp \left\{b_{2} \cdot\left(\sum_{i}^{n} a_{i} \cdot x_{i}+\text { const }\right)\right\}} \\
I_{\text {crash }}=V(x)^{b_{1}}=\left(\sum_{i}^{n} a_{i} \cdot x_{i}+\text { const }\right)^{b_{1}}
\end{gathered}
$$

ここに, $V(x)$ : 評価関数, $x_{i}$ : 幾何構造要素 $i の$ 諸元值 $a_{i}$ : 幾何構造要素iの係数パラメータ, $b_{1}, b_{2}$ : 形状パラメ 一タ, const : 定数パラメータである.

評価関数 $V(x)$ は，すべての幾何構造要素を説明変数に 含めて推定しようとすると，説明変数の数が多くなり複 雑なモデルとなる，そこで，図-6に示す幾何構造要素を 代表的な幾何構造要素として選定した。 すなわち以下の 式(15)により与えられるものとする.

$$
\begin{gathered}
V(x)=a_{1}\left(\theta_{u p}-90\right)+a_{2}\left(\theta_{\text {down }}-90\right) \\
+a_{3} \alpha_{\text {in }}+a_{4} \alpha_{c f t}+a_{5} \theta_{\text {ent }}+\text { const }
\end{gathered}
$$

ここに， $\theta_{\text {up }}$ : 上流側流入部との交差角度 $[\mathrm{deg}], \theta_{\text {down }}$ ： 下流側流入部との交差角度 $[\mathrm{deg}], \alpha_{i n}$ : 流入車両の偏差角 [deg], $\alpha_{c t t}$ : 環道車両の偏差角 $[\mathrm{deg}], \theta_{e n t}$ : 流入部接続角 度[deg]である.

\begin{tabular}{|c|c|c|c|c|c|}
\hline \multirow{2}{*}{\multicolumn{2}{|c|}{ 幾何構造要素 }} & \multicolumn{2}{|c|}{ 見落とし確率 } & \multicolumn{2}{|c|}{ 衝突強度 } \\
\hline & & \multirow{2}{*}{\begin{tabular}{|l|} 
係数 \\
-23.9 \\
\end{tabular}} & \multirow{2}{*}{\begin{tabular}{c|}
$\mathrm{t}$ 值 \\
-0.0046 \\
\end{tabular}} & \multirow{2}{*}{\begin{tabular}{r|} 
係数 \\
1.04 \\
\end{tabular}} & \multirow{2}{*}{\begin{tabular}{|l|}
$\mathrm{t}$ 值 \\
0.018 \\
\end{tabular}} \\
\hline 定数項 & const & & & & \\
\hline $\begin{array}{l}\text { 上流側流入部 } \\
\text { 交差角 }[\mathrm{deg}]\end{array}$ & $a_{1}$ & $\begin{array}{r}5.48 \times 10^{-2} \\
\left(\theta_{\mathrm{lp}}<90 \mathrm{deg}\right)\end{array}$ & $3.03^{* * * *}$ & $4.88 \times 10^{5}$ & $18.1^{* * *}$ \\
\hline $\begin{array}{l}\text { 下流側流入部 } \\
\text { 交差角 [deg] }\end{array}$ & $a_{2}$ & $-2.59 \times 10^{2}$ & $-3.21 * * *$ & $-1.66 \times 10^{4}$ & $-16.2^{* * *}$ \\
\hline $\begin{array}{c}\text { 偏差角（流入車両） } \\
{[\mathrm{deg}]}\end{array}$ & $a_{3}$ & $-3.57 \times 10^{-3}$ & $-2.42 * * *$ & $-1.50 \times 10^{-5}$ & $1.47^{*}$ \\
\hline $\begin{array}{c}\text { 偏差角（環道車両） } \\
\text { [deg] }\end{array}$ & $a_{4}$ & $1.97 \times 10^{2}$ & $2.84 * * *$ & $-5.67 \times 10^{5}$ & $-15.0^{* * *}$ \\
\hline $\begin{array}{c}\text { 流入部接続角度 } \\
\text { [deg] }\end{array}$ & $a_{5}$ & $3.12 \times 10^{-1}$ & $3.44 * * *$ & $4.97 \times 10^{5}$ & $6.05^{* * *}$ \\
\hline \multirow[t]{2}{*}{ 形状パラメータ } & $b_{1}$ & 47.3 & 0.0651 & 138.4 & 0.0067 \\
\hline & $b_{2}$ & $3.59 \times 10^{-1}$ & 0.00034 & - & \\
\hline \multicolumn{2}{|l|}{ 補正後 R ${ }^{2}$} & \multicolumn{2}{|c|}{0.64} & \multicolumn{2}{|c|}{0.85} \\
\hline \multicolumn{2}{|l|}{ サンプル数 } & \multicolumn{2}{|c|}{20,000} & \multicolumn{2}{|c|}{20,000} \\
\hline
\end{tabular}

偏差角や流入部接続角度は，実際の設計手順上，直接 その寸法值を与えるのではなく，外径や環道幅員，隅角 部の曲線半径等の幾何構造要素を決定したうえで，これ
表-5 見落とし確率と衝突強度のパラメータ推定結果

ら幾何構造要素の組合せによって付随的に決定される幾 何構造要素である.つまり，複数の幾何構造要素の影響 を包含した幾何構造要素であるとともに，見落とし確率 や衝突強度に対して，相関の高い幾何構造要素であった ため，これらを説明変数として採用した。

\section{(4) パラメータ推定結果}

数值シミュレーションによって得られた，20,000通り の幾何構造条件における見落とし確率，衝突強度の算出 結果を基に，最小二乗法による非線形重回帰分析を行っ たところ，表-5の推定結果が得られた。ただし，上流側 流入部との交差角が90deg以上の場合については，上流 側流入部との交差角度が見落とし確率に対してほとんど 影響しないことがシミュレーション結果で明らかになっ たため, $\theta_{u p}>90 \mathrm{deg} の$ 場合は $a_{1}=0$ である. 
図-7は，得られた推定結果から，モデルの説明変数 である幾何構造要素が見落とし確率，衝突強度に与える 影響の感度を見たものである．上流側流入部との交差角 度については，90deg以下では見落とし確率が増大寸る ことがわかる，衝突強度については，交差角度が大きい ほど衝突強度も高くなっている. 次に偏差角に関しては, 流入車両・環道車両ともに見落とし確率に対しては感度 が小さい. しかし，衝突強度に対しては感度が見られ， 偏差角が小さいほど衝突強度は高い。これは，偏差角が 小さいほど軌跡の曲線半径が大きくなり，その結果，式 (5)の関係式で示されるように速度が高くなるためであ る. とくに環道車両に対しては，その影響が顕著である. さらに，流入部接続角度に関しては，流入部接続角度が 大きいほど見落とし確率は減少し，一方で衝突強度は増 加する．ただし，見落とし確率に対しての影響が極めて 大きいため, 流入部接続角度は大きい方が良いものと判 断される.

図-8および図-9は，数值シミュレーションにおける 20,000通りの幾何構造条件に対して，見落とし確率およ び衝突強度のシミュレーション計算値とモデルによる推 定值をそれぞれ比較したものである．全体的に45線に 近い箇所にプロットが集中しており，5つの幾何構造要 素だけで見落とし確率と衝突強度を推定することが可能 になったと考えられる．しかし見落し確率が高い領域に おいては，モデル式による推定值は 0.8 程度に高止まり している一方，シミュレーション上では 1 に近い見落と し確率が算出されている. 数值シミュレーションによる 計算上は流入車両のドライバーは視線移動や首振り行動 をしないと仮定したため, 流入角度や上流側流入部との 交差角度が極めて小さい場合に，常に環道車両が視認で きない状況が続き，見落とし確率が1，すなわち全流入 車両のドライバーが環道車両を見落とすという結果にな る.しかしながら，このような環道を視認しにくい幾何 構造ほど，流入車両のドライバーは意識的に安全確認の 行動をしようとするため, 見落とし確率が1になるよう な状況は現実的には考えにくい. したがって，見落とし 確率が 0.8 程度で高止まりするモデル式としても実用上 は問題ないものと考えられる。

\section{7. まとめ}

本研究では，ラウンドアバウトの幾何構造条件のみか ら安全性能を評価することを目的として，見落とし確率 と衝突強度を組合せたリスク指標の考え方とその算出方 法を提案し，幾何構造と安全性能の関倸性をモデル化し た. また20,000通りの幾何構造条件における数值シミュ レーション結果に基づき, 幾何構造条件からリスク指標 を算出するためのモデル化を行った，その結果，上流側

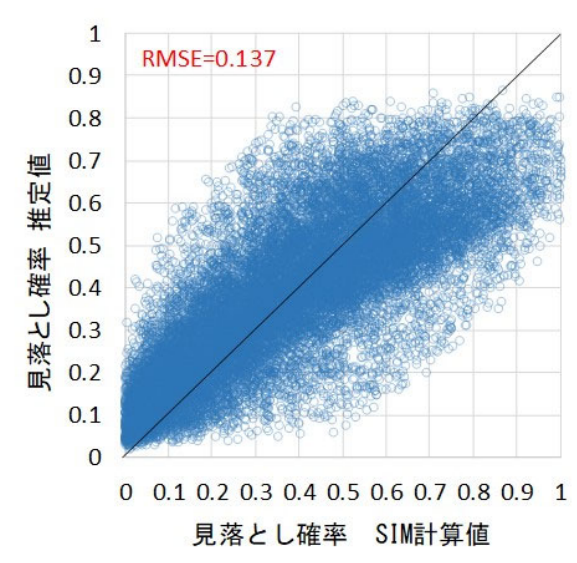

図-8＼cjkstart見落とし確率のモデル推定值と SIM 計算值

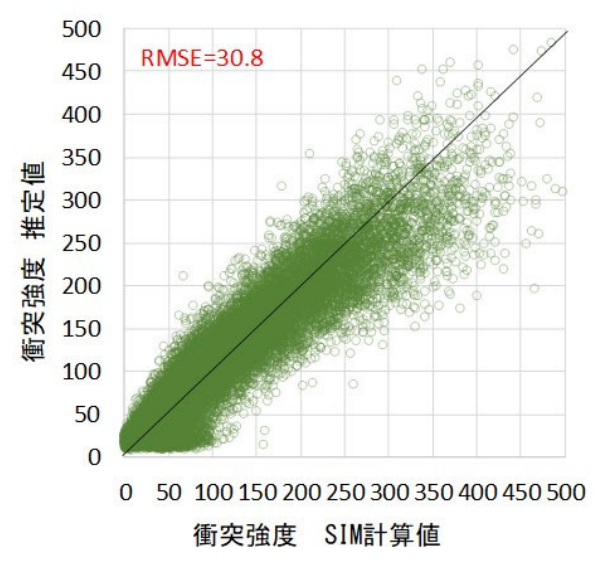

図-9 衝突強度のモデル推定值と SIM 計算值

流入部との交差角度が90degを下回る場合や流入部接続 角度が小さい際に見落とし確率が増大しやすいこと，ま た衝突強度に対しては，下流側流入部との交差角度が小 さいほど，あるいは偏差角が小さいほど衝突強度が高く なることが明らかになった. 本研究で提案するモデル式 を用いることで, 幾何構造設計の安全性能を定量的に評 価し，客観的に設計の是非を判断することが可能になる ものと考えられる.

今後の課題として, リスク指標の算出過程において計 算のために様々な前提条件を設定しており，これらの妥 当性について検証が必要である. 例えば，見落としやす さにはドライバーの首振りによる安全確認を考慮してい ないこと，十勝型事故のように視界に入っても見落とし て事故に至るメカニズムについては扱えないこと, 中央 島高さや隅角部の建築物などの視認性に関わる要素はモ デルの対象に含まれていないことなどが挙げられる.今 後このような影響も含めて見落とし確率を推定すること も考えられる. また, 本研究では直進方向に走行寸る車 両のみを対象としたが，左折や右折方向に走行する車両 も含めたモデル化や評価が必要である. 加えて, 本研究 で定義した見落とし確率と衝突強度が，それぞれ事故の 起きやすさや事故の重度を表したものであるかどうか, 
今後事故データと照らし合わせた検証が必要である.

さらには，幾何構造設計を評価するうえでは歩行者や 自転車の扱いも重要となるため，これらを考慮した評価 方法も検討すべきである.

謝辞：本研究は，JSPS科研費基盤研究(B)16H04426の助 成を受けたものです.

\section{参考文献}

1) (一社)交通工学研究会 : ラウンドアバウトマニュアル 2016.

2) (公財)国際交通安全学会 : ラウンドアバウトの社会実 装と普及促進に関する研究(III) 報告書，2015.

3) 小林寛, 今田勝昭, 上野朋弥, 高宮進 : ラウンドア バウトのエプロン構造の違いによる車両走行特性に 関する実験検討，第 51 回土木計画学研究発表会・講 演集，CD-ROM， 2015.

4) Maycock, G. and Hall, R. D.: Accidents at 4-arm roundabouts, Transportation Research Laboratory Report LR1120, 1980.

5) Arndt, O. K. and Troutbeck, R. J.: Relationship between roundabout geometry and accident rates, Transportation Research Circular, Vol. 28, pp. 1-16, 1998.

6) Transportation Research Board: NCHRP Report 572 Roundabouts in the United States, 2007.

7) Transportation Research Board: NCHRP Report 672 Roundabouts; An informational guide, 2nd edition, 2010.

8) Vereinigung Schweizerischer Strassenfachleute: Schweizer Norm SN 640 263, Knoten mit Kreisverkehr, 1999.

9) Spacek, P.: Basis of the Swiss design standard for roundabout, Transportation Research Record, No. 1881, pp. 27-35, 2004.

10) Guido, G., Saccomanno, F., Vitale, A., Astarita, V. and Festa, D.: Comparing safety performance measures obtained from video capture data, Journal of Transportation Engineering, Vol. 137, No. 7, pp. 481-492, 2011.

11) Mussone, L.: The analysis of roundabouts through visibility, Procedia - Social and Behavioral Sciences, Vol. 87, pp. 250-268. 2013.
12) Gettman, D. and Head, L.: Surrogate safety measures from traffic simulation models, Transportation Research Record, Vol. 1840, pp. 104-115, 2003.

13) International Organization for Standardization/ International Electrotechnical Commission (ISO/IEC): Guide 51 Safety aspects Guidelines for their inclusion in standards, 2014

14）吉井稔雄，兵頭知，倉内慎也：都市内高速道路にお ける事故発生リスク要因分析, 第 31 回交通工学研究 発表会論文集，2013.

15) 蓮花一己：運転時のリスクテイキング行動の心理的 過程とリスク回避行動へのアプローチ，国際交通安 全学会誌, Vol. 26, No. 1, pp. 12-22, 2010.

16）若林拓史，高橋吉彦，新美栄浩，蓮花一己：交通流 ビデオ解析システムを用いた交通コンフリクト分析 と新しい危険度評価指標の提案, 土木計画学研究 論文集，Vol. 20, No. 4, pp. 949-956, 2003.

17) 鈴木弘司, 藤田素弘, 小塚一人, 串原喜之: 利用者 のリスクテイキング/回避行動を考慮した信号交差点 の運用評価に関する研究, 土木計画学研究・論文集, Vol. 22, No. 4, pp. 853-862, 2005.

18）中村英樹，馬㴊太樹：車両間交錯度を考慮したラウ ンドアバウトと信号交差点の性能比較分析，交通工 学, Vol. 41, No. 5, pp. 69-79, 2006.

19) Alhajyaseen, W. K. M.: The development of conflict Index for the safety assessment of intersections considering crash probability and severity, Procedia Computer Science, Vol. 32, pp. 364-371, 2014.

20) Alhajyaseen, W. K. M., Asano, M. and Nakamura, H.: Estimation of left-turning vehicle maneuvers for the assessment of pedestrian safety at intersections, IATSS Research, Vol. 36, pp. 66-74, 2012.

21）森島圭祐, 水内淳, 阿部光一郎, 古木翔, 山中仁寛, 大本浩司：眼球・頭部非固定における自動車運転時 の有効視野計測, 日本機械学会論文集(C 編), 79 巻 806 号, pp. 3561-3573, 2013.

(Received May 29, 2019)

(Accepted July 26, 2019)

\title{
MODELING A RISK INDEX FOR EVALUATING THE SAFETY PERFORMANCE OF ROUNDABOUT GEOMETRIC DESIGN
}

\author{
Keisuke YOSHIOKA, Hideki NAKAMURA, Sumio SHIMOKAWA \\ and Hirohisa MORITA
}

For the geometric design of a roundabout, a safety-oriented approach is required rather than a simple specification dependent design that normatively determines dimensions of the geometric elements. However, such a safety performance index or evaluation methodology has yet to be included in the Japanese guidelines. In this study, we propose a risk index (RI) that combines the mislook probability and crash impact as a performance index for evaluating the safety of roundabout geometric designs; a method to calculate this index is also described. Then, a model equation to calculate the RI from the geometric conditions throughout the numerical simulation is presented. Finally, it is demonstrated that the mislook probability is greater when the entry angle is lower, and the crash impact increases when the deviation angle decreases. 